\title{
Fuel Properties of Indonesian Bamboo Carbonized at Different Temperatures
}

\author{
Se Hwi Park, ${ }^{\mathrm{a}}$ Jae Hyuk Jang, ${ }^{\mathrm{b}}$ Nyoman J Wistara, ${ }^{\mathrm{a}}$ Fauzi Febrianto, ${ }^{\mathrm{a}}$ and Min Lee ${ }^{\mathrm{b}, *}$ \\ Bamboo can be used in a variety of ways, including as fuel and as \\ household and construction materials. Due to its versatility, the material \\ is of high economic value. This study investigated the fuel properties of \\ six bamboo species grown in Indonesia. Each bamboo sample was \\ carbonized at different temperatures. Proximate and ultimate analyses \\ were carried out on the bamboo samples. The thermal maturity of the \\ bamboo samples as a solid fuel was investigated by the van Krevelen \\ diagram. The efficiency of bamboo at each carbonizing temperature was \\ determined based on the char yield, energy densification rate, energy \\ efficiency, and calorific value. The results showed that the ash and fixed \\ carbon contents of carbonized bamboo increased with an increasing \\ carbonization temperature; while the volatile matter decreased. \\ Significant changes in the fuel properties were observed between $200{ }^{\circ} \mathrm{C}$ \\ and $400{ }^{\circ} \mathrm{C}$. Carbonized bamboos showed lower sulfur contents in \\ comparison to other fossil fuels. Ampel bamboo showed a calorific value \\ of $18 \mathrm{MJ} / \mathrm{kg}$ to $32 \mathrm{MJ} / \mathrm{kg}$, which was the highest value among the \\ samples. Bamboo carbonized at temperatures above $600{ }^{\circ} \mathrm{C}$ showed a \\ thermal maturity of coal grade. The results of this study can be used for \\ utilizing Indonesian bamboo as a fuel source.
}

Keywords: Carbonization; Indonesian bamboo; Proximate and Ultimate analysis; van Krevelen diagram

Contact information: a: Department of Forest Product, Faculty of Forestry, Bogor Agricultural University, GD. Fahutan Kampus IPB Dramaga, Bogor 16680, Indonesia; b: Department of Forest Products, National Institute of Forest Science, Seoul 02455, Republic of Korea; *Corresponding author: mlee81@korea.kr

\section{INTRODUCTION}

Fossil fuels have been the main energy source for mankind since the invention of the internal combustion engine. The continued usage of fossil fuels should be regulated, as it is the main cause of global environmental pollution and climate change. Furthermore, an agreement was reached on the theme of reducing greenhouse gas (GHG) emissions through the Kyoto Protocol to the United Nations framework convention on climate change, and a binding reduction target was given to developed countries. Europe and North American countries have pursued improvements in energy efficiency and forestation, as well as the development of alternative energy, to solve this problem. The development of sustainable energy sources has been emphasized as it solves environmental problems and strengthens national energy independence (Sims 2004).

Biomass refers to plants that synthesize organic matter with solar energy that is then ingested by biological organisms such as animals and microorganisms. Biomass can be converted into chemical energy through pyrolysis or fermentation (Klass 1998). Charcoal, biogas, bioethanol, biodiesel, and methanol are produced through various processes and can be used for cooking, heating, and automobile fuel (Demirbaş 2003). In 
addition, biomass, unlike fossil fuels, can be produced in a relatively short time and produce less environmental pollution (Bial et al. 2013). However, like other alternative energy resources, the drawbacks of biomass that hinder its expansion across the market are its low efficiency and high manufacturing costs. For example, grain-based bioethanol, i.e., first-generation bioethanol, puts pressure on food supplies and consumes a largescale of land for its production. Similarly, wood-based bioethanol (second-generation) is not suitable due to the difficulty in crafting a sufficient supply and the inefficiency of the hydrolysis process. As a result, researchers have been trying to find new biomass resources from herbaceous, seaweed, and waste materials (Beer et al. 2009; Ahn et al. 2014; Bilal et al. 2017).

Bamboo, an herbaceous plant, is a highly valuable biomass resource in Indonesia because of its fast growth rate and the total gross area. Bamboo occupies $3.2 \%$ of the world's forest area, and approximately $65 \%$ of this bamboo is grown in Asia. Following India and China, Indonesia is $3^{\text {rd }}$ in bamboo forest area (1.4 million ha, Table 1). In Indonesia, bamboo has been used for architecture, household goods, furniture, musical instruments, textiles, and mats after first simple physical processing. However, the use of bamboo has gradually decreased due to the development of alternative materials such as plastic. In addition, bamboo exports from Indonesia in 2015 (1.5 million US \$) did not even reach half of the exported amount in 2007 (3.0 million US\$, Park et al. 2018).

Indonesian bamboo species show distinctive characteristics that include larger volumes (greater diameters and heights) than other bamboo species such as Moso bamboo (Phyllostachys edulis), which is a common species in the Asia region. Indonesian bamboos exhibit sympodial growth, indicating that these bamboos can be harvested as a mass volume in one place. Sympodial growth type bamboo grows together like a bundle, but monopodial growth type bamboo grows individually (Fig. 1). Therefore, sympodial growth presents advantages in harvesting and workability. For these reasons, the Indonesian government regards bamboo as an important agroforestry product. Under the certain goal of promoting bamboo's usage in daily life and replacing wood resources, the bamboo industry has been developed around Central Java, West Java, East Java, Bali, and Yogyakarta (Hardiani and Dewy 2014). Despite the previously mentioned advantages, Indonesian bamboo is mainly used for simple products such as construction materials, musical instruments, and food stuffs (Yudodibroto 1985). Considering its versatility, the development of bamboo as a new renewable energy source is needed.

Many studies, primarily in East-Asia and North America, have been conducted on bamboo biomass for environmental carbon materials. The relationship between the carbonizing temperature of bamboo and the removal of harmful gases has been analyzed (Asada et al. 2002). An efficient process for the production of fuel ethanol from bamboo has been developed (Sun et al. 2011). Bamboo charcoal effectively adsorbs and removes cesium from wastewater (Khandaker et al. 2017). Although Indonesia has many bamboo resources, there is little research on the utilization of bamboo for energy resources.

This study was conducted to determine which Indonesian bamboo species are appropriate for use as a renewable energy raw material. The fundamental data for fuel properties were analyzed by species and carbonization temperatures. Furthermore, it is hoped that this data will support and encourage the Indonesian government, which is still a beginner with respect to the utilization of bamboo. 

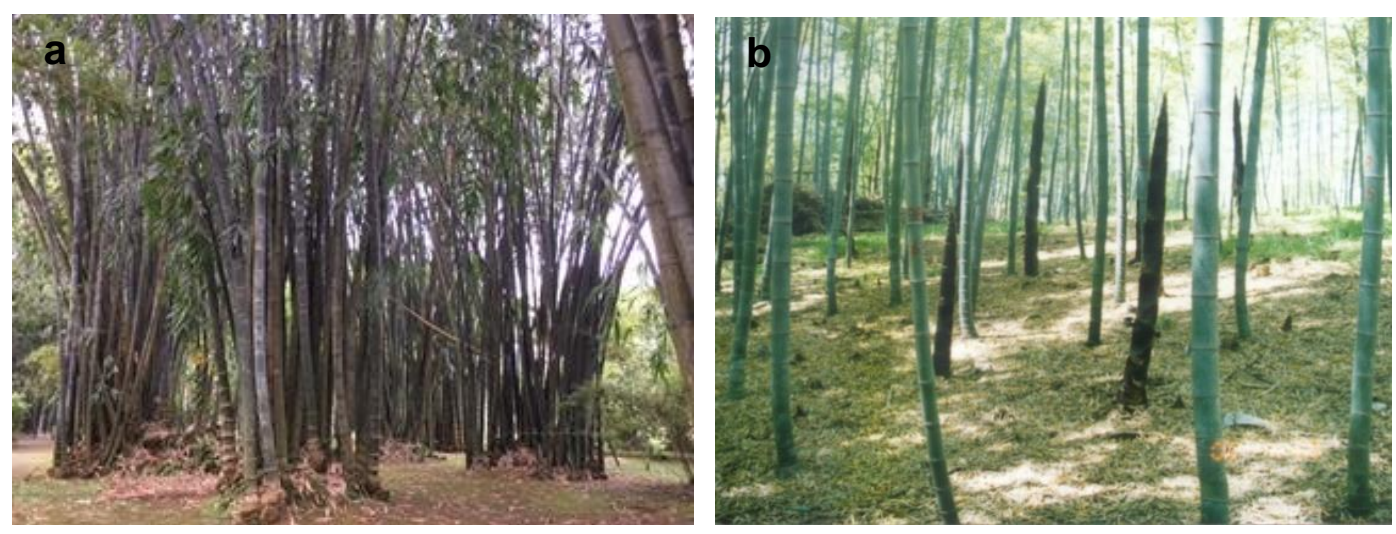

Fig. 1. Pictures of a) sympodial growth type bamboo (Andong, Gigantochloa pseudoarundinacea (Steudel) Widjaja) and b) monopodial growth type bamboo (Moso, Phyllostachys edulis)

\section{EXPERIMENTAL}

\section{Materials}

Six Indonesian bamboo species were used in this research: Andong (Gigantochloa pseudoarundinacea (Steudel) Widjaja), Hitam (G. atroviolacea Widjaja), Tali (G. apus Schult. \& Schult. F.), Kuning (Bambusa vulgaris var. striata), Ampel (B. vulgaris Scharad), and Betung (Dendrocalamus asper Schult. F.). The above bamboo samples were collected at the second node from the ground at Bogor $\left(6^{\circ} 20^{\prime} 21^{\prime \prime} \mathrm{S}, 106^{\circ} 33^{\prime} 58^{\prime} \mathrm{E}\right)$. The bamboo samples were naturally dried for 3 months in ambient condition and then cut into $25 \mathrm{~mm}$ (width) x $40 \mathrm{~mm}$ (length) pieces. Detailed information for each species is given in Table 2.

Table 1. Distribution of Bamboo Forest in Indonesia

\begin{tabular}{|c|r|r|}
\hline Province & No. of clump & Estimated area (ha) \\
\hline West Java & $10,651,743$ & 343,604 \\
\hline Central Java & $8,186,878$ & 264,093 \\
\hline East Java & $7,348,613$ & 237,052 \\
\hline North Sumatra & 818,593 & 102,324 \\
\hline South Sulawesi & $1,397,941$ & 53,767 \\
\hline Others & $9,569,147$ & 413,535 \\
\hline Total & $37,972,9006$ & $1,414,375$ \\
\hline
\end{tabular}

Table 2. General Information of Bamboo Species Used in This Study

\begin{tabular}{|c|l|c|c|c|c|}
\hline Species & \multicolumn{1}{|c|}{ Scientific Name } & $\begin{array}{c}\text { Age } \\
(\text { year })\end{array}$ & $\begin{array}{c}\text { Avg. } \\
\text { Diameter * } \\
(\mathrm{cm})\end{array}$ & $\begin{array}{c}\text { Avg. } \\
\text { Thickness } \\
(\mathrm{mm})\end{array}$ & $\begin{array}{c}\text { Avg. } \\
\text { Density } \\
\left(\mathrm{g} / \mathrm{cm}^{3}\right)\end{array}$ \\
\hline Andong & Gigantochloa pseudoarundinacea & 5 & 12.1 & 12.5 & 0.71 \\
\hline Hitam & G. atroviolacea & 5 & 8.3 & 10.8 & 0.71 \\
\hline Tali & G. apus & 5 & 8.1 & 9.7 & 0.60 \\
\hline Kuning & Bambusa vulgaris (var. striata) & 5 & 7.9 & 17.3 & 0.67 \\
\hline Ampel & B. vulgaris (Scharad) & 5 & 7.0 & 13.3 & 0.77 \\
\hline Betung & Dendrocalamus asper & 5 & 14.0 & 22.4 & 0.56 \\
\hline * Diameter of second node from ground level & \multicolumn{5}{|l}{} \\
\hline
\end{tabular}




\section{Methods}

\section{Carbonization}

The bamboo samples were wrapped in paper and aluminum foil and then placed in heat-resistant containers (Park and Park 2012). The prepared samples were carbonized in a laboratory electric furnace (TST BT-F724, Daeyang Ins., Yeoju, Korea). The heating rate was set at $50{ }^{\circ} \mathrm{C} / \mathrm{h}$ and maintained at varied target temperatures of 200, 400, 600, 800 , and $1000{ }^{\circ} \mathrm{C}$ for $2 \mathrm{~h}$ (Fig. 2). Carbonized specimens were ground, sieved to pass the $150 \mathrm{mesh}$, and then used for proximate and ultimate analyses.

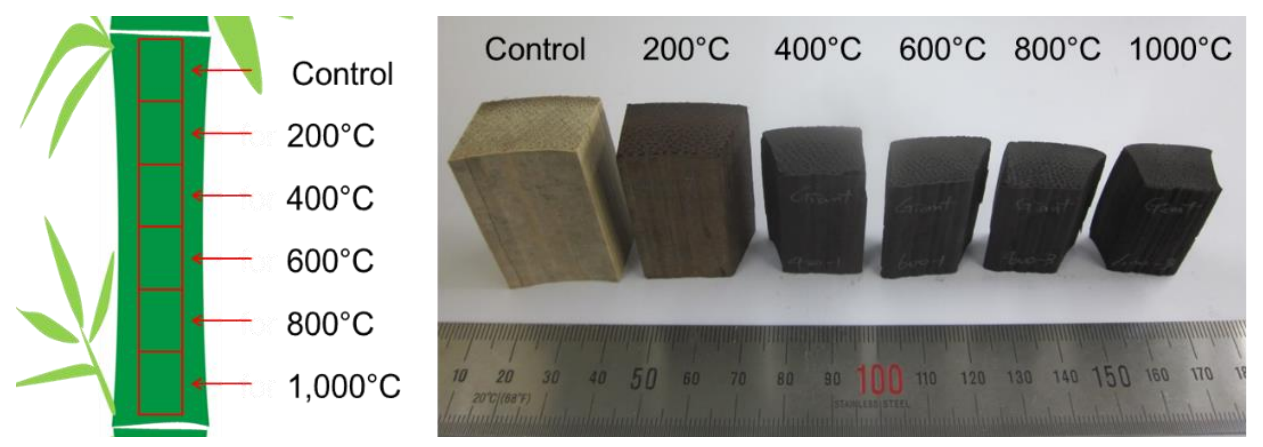

Fig. 2. Picture of the original and carbonized bamboo samples at different temperatures

\section{Fuel properties}

The fuel properties of original bamboo and carbonized bamboo were investigated by proximate analysis and ultimate analysis. The volatile matter and ash contents were measured according to KS E ISO 562 (KSA 2012a) and KS E ISO 1171 (KSA 2012b) for the proximate analysis. The fixed carbon content (FCC) was calculated based on the following formula,

$$
F C C(\%)=1-M-V M-A S H
$$

where $M, V M$, and $A S H$ represent the moisture content (\%), the volatile matter (\%), and the ash content $(\%)$, respectively, of the specimens.

An elemental analyzer (Elementar Vario MACRO cube, Langenselbold, Germany) was used to determine the contents of carbon, hydrogen, nitrogen, and sulfur. Approximately $30 \pm 5 \mathrm{mg}$ of the sample was wrapped in silver foil and put in a sampler. Soil standard (certificate 133317; carbon $2.29 \% \mathrm{w} / \mathrm{w}$, nitrogen $0.2 \% \mathrm{w} / \mathrm{w}$, and sulfur $0.023 \% \mathrm{w} / \mathrm{w}$ ) was used as an analytical reference material. During the analysis, the oxidation tube temperature and the reduction tube temperature of the elemental analyzer were maintained at $1050{ }^{\circ} \mathrm{C}$ and $830{ }^{\circ} \mathrm{C}$, respectively. The oxygen content was calculated by subtracting the sum of carbon, nitrogen, hydrogen, and sulfur components. The calorific value was analyzed using a calorimeter (Parr 6300 calorimeter, Parr Instrument, Moline, IL, USA) according to Korean Standard KS E 3707 (2016).

\section{Fuel efficiency}

The char yield (Eq. 2), energy densification ratio (Eq. 3), and energy yield (Eq. 4) were calculated to evaluate the overall fuel efficiency (Hidayat et al. 2017),

$$
\text { Char yield }(\%)=W_{c} / W_{o} \times 100
$$

Energy densification ratio $=C V_{c} / C V_{o}$ 


$$
\text { Energy yield }(\%)=(2) \times(3)
$$

where $W_{c}$ and $W_{o}$ represent the oven-dried weight $(\%)$ of the carbonized and original specimens, and $C V_{c}$ and $C V_{o}$ represent the calorific value $(\mathrm{MJ} / \mathrm{kg})$ of the carbonized and original specimens.

In order to evaluate the thermal maturity of the original and carbonized bamboo samples as a solid fuel, a van Krevelen diagram by species and carbonization temperature was drawn for each sample according to the data from the equation below (Jones et al. 2006).

$$
[H / C]=1.412[O / C]+0.5004
$$

where $\mathrm{H}, \mathrm{C}$, and $\mathrm{O}$ represent hydrogen, carbon and oxygen content $(\%)$ of samples.

\section{RESULTS AND DISCUSSION}

\section{Fuel Properties of Original Bamboo}

The fundamental properties of the original bamboo were analyzed to compare measurements with carbonized bamboo and determine the best way to use the material commercially (Table 3 ). The moisture contents (MC) of all species ranged from $7.1 \%$ to 10.2\%. The Ampel bamboo showed a higher MC, while the Betung bamboo showed a lower MC. The moisture content of Indonesian bamboo is much higher than that of other bamboo that grows in Korea and Japan (less than 5\%). This is a reasonable result considering the result of observing the high thickness of woody part and growing weather.

\begin{tabular}{|c|c|c|c|c|c|c|c|c|c|c|}
\hline \multirow{2}{*}{ Species } & \multicolumn{4}{|c|}{ Proximate analysis (\%) } & \multicolumn{5}{|c|}{ Ultimate analysis (\%) } & \multirow{2}{*}{$\begin{array}{c}\mathrm{CV}^{*} \\
(\mathrm{MJ} / \mathrm{kg})\end{array}$} \\
\hline & $\mathrm{MC}$ & Ash & VMC $^{*}$ & $\mathrm{FCC}^{\star \star}$ & $\mathrm{C}$ & $\overline{\mathrm{H}}$ & $\mathrm{O}$ & $\mathrm{N}$ & $\mathrm{S}$ & \\
\hline Andong & 8.4 & 2.08 & 78.0 & 11.5 & 49.0 & 6.09 & 44.4 & 0.40 & 0.05 & 18.65 \\
\hline Hitam & 7.8 & 1.36 & 72.4 & 18.4 & 50.3 & 6.21 & 42.9 & 0.46 & 0.05 & 18.75 \\
\hline Tali & 7.3 & 1.89 & 80.0 & 10.8 & 50.9 & 6.44 & 42.3 & 0.24 & 0.07 & 18.70 \\
\hline Kuning & 7.6 & 2.68 & 75.4 & 14.3 & 48.2 & 6.08 & 45.2 & 0.39 & 0.05 & 18.84 \\
\hline Ampel & 10.2 & 1.15 & 72.0 & 16.7 & 49.5 & 6.30 & 43.7 & 0.43 & 0.04 & 18.27 \\
\hline Betung & 7.1 & 2.44 & 75.4 & 15.1 & 48.7 & 6.00 & 44.9 & 0.33 & 0.05 & 18.41 \\
\hline
\end{tabular}

Table 3. Fuel Properties of Original Bamboo Samples

In the proximate analysis of all bamboo species, the ash, volatile matter, and fixed carbon were in the range of $1.1 \%$ to $2.7 \%, 72 \%$ to $80 \%$, and $10 \%$ to $18 \%$, respectively. In the ultimate analysis of all the bamboo species, the carbon, hydrogen, oxygen, nitrogen, and sulfur contents were in the range of $48.2 \%$ to $50.9 \%, 6.00 \%$ to $6.44 \%, 42.3 \%$ to $45.2 \%, 0.24 \%$ to $0.46 \%$, and $0.04 \%$ to $0.07 \%$, respectively. The calorific value of all the bamboo species was $18.2 \mathrm{MJ} / \mathrm{kg}$ to $18.8 \mathrm{MJ} / \mathrm{kg}$, and there was no significant difference among the species. The low calorific value of original bamboo was attributed to the high water content and the effect of VMC. These results were similar to those reported by Hernandez-Mena et al. (2014) and Kumar and Chandrashekar (2014) for the Bambusa and Dendrocalamus genus. 


\section{Fuel Properties of Carbonized Bamboo}

The results of the proximate and ultimate analysis of bamboo after being carbonized at different temperatures are shown in Table 4. The ash contents of carbonized bamboo (c-bamboo) samples varied from $1.3 \%$ to $10.8 \%$ according to the carbonization temperatures. In general, biomass with a high ash content is not preferred because it negatively affects the calorific value and combustion quality. Ampel cbamboo, which has a lower ash content than others, might be preferred for good fuel quality. The values of volatile matter of each sample ranged from $4.7 \%$ to $77.7 \%$. The volatile matter of all the species decreased with an increasing carbonization temperature, especially at carbonization temperatures between $200{ }^{\circ} \mathrm{C}$ and $400{ }^{\circ} \mathrm{C}$. Qian et al. (2004) reported that $80 \%$ of the total weight loss occurred due to volatilization of hydrogen and oxygen at $260{ }^{\circ} \mathrm{C}$ to $400{ }^{\circ} \mathrm{C}$. Volatiles are closely related to rapid ignition, but high volatiles generate soot and smoke, which is a factor to be avoided during combustion.

Carbonized Ampel, Hitam, and Andong bamboo showed higher fixed carbon contents than other bamboo species at most of the carbonization temperatures. The fixed carbon, which represents the amount of carbon contained in solid fuel, is an important indicator in determining calorific value. The fixed carbon of Hitam showed the highest value at $200{ }^{\circ} \mathrm{C}$ and $1000{ }^{\circ} \mathrm{C}$, while that of Ampel and Andong showed the highest value at $600{ }^{\circ} \mathrm{C}$ and $800{ }^{\circ} \mathrm{C}$, respectively. Hidayat et al. (2017) reported that fixed carbon of Indonesian wood species, such as Albizia ( $P$. falcataria), Gmelina (G. arborea), Mindi (M. azedarach) and Mangium (A. mangium), were in the range of 22 to $29 \%$ at control, 58 to $70 \%$ at $400{ }^{\circ} \mathrm{C}, 70$ to $70 \%$ at $600{ }^{\circ} \mathrm{C}$, and 73 to $83 \%$ at $800{ }^{\circ} \mathrm{C}$. The bamboo species used in this study showed lower fixed carbon contents than Indonesian wood species. The fixed carbon of Hitam and Ampel bamboo, however, represented a somewhat close value to wood materials mentioned above.

In the ultimate analysis, the carbon, hydrogen, and oxygen contents of the cbamboo samples varied depending on carbonization temperatures. Bamboo and other biomass showed a large difference depending on the content of moisture, lignin, and cellulose in the initial stage (below $400{ }^{\circ} \mathrm{C}$ ) of the pyrolysis process, but as the carbonization temperature was increased, the results of ultimate analysis showed a similar trend. With an increasing carbonization temperature, carbon contents increased, while the oxygen and hydrogen contents decreased. During the carbonization, O, N, S, etc. bound to the initial $\mathrm{C}$ are dissociated, and the content of $\mathrm{C}$ is increased (Zuo et al. 2003). The major changes of carbon, oxygen, and hydrogen contents were observed between $200{ }^{\circ} \mathrm{C}$ and $400{ }^{\circ} \mathrm{C}$. These changes were caused by mainly volatile emissions and the enrichment of residual charcoal matrices with aromatic compounds (Biagini et al. 2008). Exceptionally, unlike other elements, sulfur was detected in trace amounts. This is a major advantage of biomass materials when compared to fossil fuels. For example, conventional fuels such as lignite and anthracite coal generate a large amount of sulfur during combustion. Therefore, limestone should be used in large quantities to reduce sulfur emissions to the atmosphere (Pimchuai et al. 2010).

The calorific value refers to the amount of heat released when combustion fuel is completely burned. The measure represents an important criterion for the performance of fuel. The calorific value of carbonized bamboo at different temperatures is shown in Fig. 3 . The calorific value of all species generally increased to a carbonization temperature of $600{ }^{\circ} \mathrm{C}$ due to decrease of volatile matter and increase of fixed carbon. 
Table 4. Fuel Properties of Carbonized Bamboo Samples

\begin{tabular}{|c|c|c|c|c|c|c|c|c|c|}
\hline \multirow{2}{*}{$\begin{array}{l}\text { Carbonization } \\
\text { Temperature } \\
\left({ }^{\circ} \mathrm{C}\right)\end{array}$} & \multicolumn{4}{|c|}{ Proximate Analysis (\%) } & \multicolumn{5}{|c|}{ Ultimate Analysis (\%) } \\
\hline & $\mathrm{MC}$ & Ash & $\mathrm{VMC}^{*}$ & $\mathrm{FCC}^{* *}$ & C & $\mathrm{H}$ & 0 & $\mathrm{~N}$ & $S$ \\
\hline Andong & & & & & & & & & \\
\hline 200 & 4.8 & 3.1 & 77.1 & 15.0 & 53.0 & 5.78 & 40.6 & 0.49 & 0.06 \\
\hline 400 & 5.0 & 5.7 & 28.4 & 60.8 & 74.7 & 3.19 & 21.1 & 0.82 & 0.11 \\
\hline 600 & 6.1 & 7.9 & 11.0 & 78.8 & 85.1 & 1.76 & 12.0 & 0.92 & 0.13 \\
\hline 800 & 7.8 & 6.8 & 11.0 & 74.5 & 86.3 & 0.96 & 11.4 & 1.15 & 0.12 \\
\hline 1000 & 6.6 & 7.7 & 10.4 & 75.4 & 88.4 & 0.69 & 9.9 & 0.85 & 0.10 \\
\hline \multicolumn{10}{|l|}{ Hitam } \\
\hline 200 & 4.3 & 2.7 & 71.4 & 21.6 & 53.7 & 5.77 & 39.8 & 0.55 & 0.05 \\
\hline 400 & 4.4 & 4.0 & 32.0 & 59.6 & 73.3 & 3.34 & 22.2 & 0.95 & 0.06 \\
\hline 600 & 3.2 & 4.4 & 15.9 & 76.5 & 83.8 & 2.74 & 12.3 & 1.06 & 0.06 \\
\hline 800 & 4.3 & 4.9 & 5.3 & 85.6 & 91.5 & 0.74 & 6.5 & 1.17 & 0.06 \\
\hline 1000 & 4.9 & 4.4 & 5.2 & 85.5 & 93.7 & 0.39 & 4.7 & 1.07 & 0.05 \\
\hline \multicolumn{10}{|l|}{ Tali } \\
\hline 200 & 3.9 & 2.9 & 77.7 & 15.5 & 53.6 & 5.82 & 40.0 & 0.36 & 0.07 \\
\hline 400 & 4.6 & 4.0 & 32.4 & 59.0 & 78.2 & 3.13 & 17.8 & 0.59 & 0.14 \\
\hline 600 & 4.6 & 4.6 & 19.3 & 71.5 & 91.8 & 2.08 & 5.2 & 0.67 & 0.16 \\
\hline 800 & 7.2 & 6.0 & 12.7 & 74.1 & 93.6 & 0.97 & 4.3 & 0.86 & 0.17 \\
\hline 1000 & 8.0 & 4.0 & 11.8 & 76.2 & 95.7 & 0.48 & 2.6 & 0.97 & 0.16 \\
\hline \multicolumn{10}{|l|}{ Kuning } \\
\hline 200 & 4.1 & 3.1 & 76.0 & 16.7 & 52.6 & 5.39 & 41.4 & 0.47 & 0.09 \\
\hline 400 & 4.9 & 7.1 & 30.7 & 57.3 & 72.9 & 2.89 & 23.3 & 0.67 & 0.16 \\
\hline 600 & 6.1 & 7.0 & 15.4 & 71.4 & 83.9 & 1.65 & 13.3 & 0.83 & 0.18 \\
\hline 800 & 7.3 & 7.9 & 15.4 & 69.3 & 86.5 & 0.73 & 11.4 & 1.14 & 0.15 \\
\hline 1000 & 7.3 & 8.3 & 8.0 & 76.3 & 87.9 & 0.40 & 10.5 & 0.99 & 0.10 \\
\hline \multicolumn{10}{|l|}{ Ampel } \\
\hline 200 & 3.9 & 1.3 & 74.6 & 20.1 & 56.0 & 5.73 & 37.6 & 0.50 & 0.04 \\
\hline 400 & 4.6 & 3.0 & 26.7 & 65.7 & 78.8 & 3.41 & 16.7 & 0.87 & 0.06 \\
\hline 600 & 4.3 & 3.0 & 15.2 & 77.5 & 89.5 & 2.41 & 6.9 & 1.01 & 0.08 \\
\hline 800 & 6.7 & 3.3 & 4.7 & 85.3 & 92.6 & 1.11 & 5.1 & 1.04 & 0.07 \\
\hline 1000 & 6.6 & 3.0 & 6.4 & 84.0 & 94.8 & 0.54 & 3.5 & 0.96 & 0.06 \\
\hline \multicolumn{10}{|l|}{ Betung } \\
\hline 200 & 4.0 & 3.7 & 71.8 & 20.4 & 53.8 & 5.71 & 40.0 & 0.41 & 0.04 \\
\hline 400 & 5.2 & 6.8 & 28.7 & 59.2 & 71.0 & 3.05 & 25.1 & 0.71 & 0.04 \\
\hline 600 & 4.6 & 7.7 & 14.9 & 72.7 & 85.2 & 1.81 & 12.0 & 0.85 & 0.05 \\
\hline 800 & 4.9 & 9.7 & 10.4 & 75.0 & 90.5 & 0.87 & 7.5 & 0.99 & 0.03 \\
\hline 1000 & 3.8 & 10.8 & 11.6 & 73.9 & 89.9 & 0.51 & 8.5 & 0.96 & 0.03 \\
\hline
\end{tabular}

* VMC: volatile matter contents

** FCC: fixed carbon contents

Generally, the heat of combustion by carbon is higher than those by volatile substances such as oxygen or hydrogen (Jones et al. 2006). For carbonization temperatures at or above $600{ }^{\circ} \mathrm{C}$, the calorific value slightly decreased due to higher ash contents that negatively affected the quality of combustion (Klass 1998). At the carbonization temperature of $600{ }^{\circ} \mathrm{C}$, the calorific values of carbonized Andong, Hitam, Tali, Kuning, Ampel, and Betung bamboo were of 31.5, 32.6, 32.7, 30.9, 32.0, and 31.4 $\mathrm{MJ} / \mathrm{Kg}$, respectively. The calorific value of Ampel, Hitam, and Tali bamboos were higher than that of the others. Park et al. (1998) studied properties of carbonized Moso bamboo grown in South Korea, where the calorific value of the carbonized Moso bamboo was in the range of $30.3 \mathrm{MJ} / \mathrm{kg}$ to $33.1 \mathrm{MJ} / \mathrm{kg}$. In the comparison of Indonesian bamboo and 
Korean (Moso) bamboo, calorific values showed similar results, but the Indonesian bamboo had a bigger diameter than the Korean bamboo. Therefore, larger diameter would be a good advantage as it would imply longer combustion times.

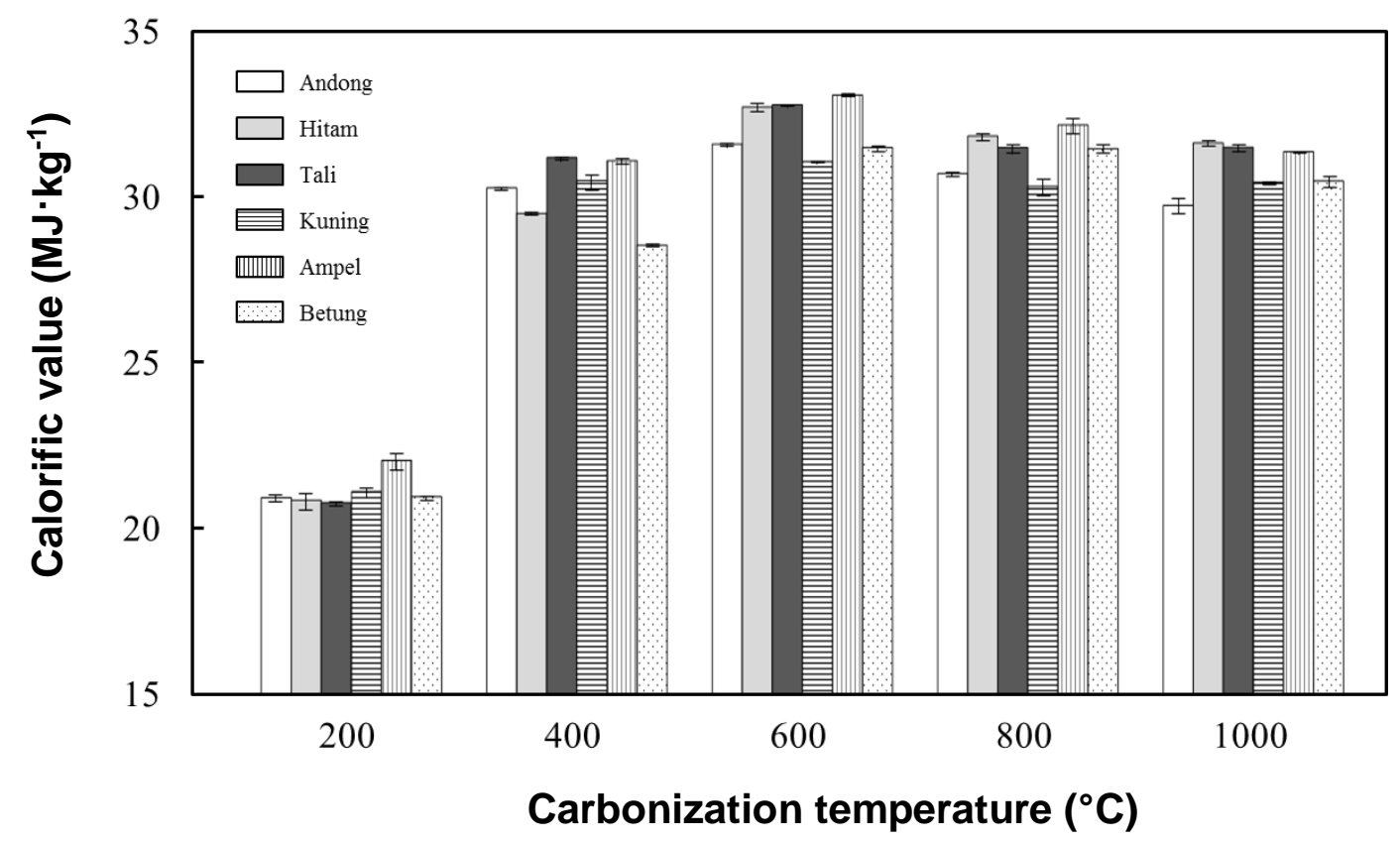

Fig. 3. Calorific value of bamboo samples carbonized at different temperatures

\section{Fuel Efficiency}

Due to its low calorific value in comparison to other solid fuels, biomass requires heat treatment processes such as gasification, semi-carbonization, and carbonization to reach the level required by the market. Calorific value of biomass increased with increasing of temperature, while those of mass and volume rapidly decreased (Bial et al. 2013). A quantitative process is needed to find the optimum carbonization condition of biomass use. Moreover, an energy efficiency analysis should be conducted to find out an appropriate application area. The energy density is calculated based on the calorific value, the main indicator of fuel, and the fuel efficiency is analyzed by comparing the char yields. The results are shown in Table 5.

The utilization of biomass depends on the amount of energy needed for the specific purpose. For example, a higher combustion heat value is needed for using charcoal, and the economic aspect is more important when using the material as pellets for households heating sources (Hidayat et al. 2017). In the general case of wood or biomass carbonization, the char yield decreased with increasing carbonization temperature. Char yield of bamboo also showed same results. No significant difference was observed among the c-bamboo speices. Kuning carbonized bamboo showed the lowest char yield $(74.1 \%)$ at $200{ }^{\circ} \mathrm{C}$ carbonization than that of others. However, on the carbonization at $1000{ }^{\circ} \mathrm{C}$, the highest char yield was observed on Kuning carbonized bamboo (28.0\%).

The highest value of energy densification was observed on all c-bamboo samples carbonized at $600{ }^{\circ} \mathrm{C}$ and then remained or slightly decreased at $800{ }^{\circ} \mathrm{C}$ and $1000{ }^{\circ} \mathrm{C}$. Based on energy densification ratio, the values of c-bamboo increased carbonization temperature from $200{ }^{\circ} \mathrm{C}$ to $600{ }^{\circ} \mathrm{C}$ and then started to decrease until $1000{ }^{\circ} \mathrm{C}$. It is the 
same pattern with char yield, which means that with increasing carbonization temperature, the energy efficiency decreased. Energy yield of c-bamboos decreased with increasing carbonization temperature. In the bamboo species comparisons, Ampel bamboo carbonized at $200{ }^{\circ} \mathrm{C}$ showed significantly higher the energy yield than that of other bamboo species. As mentioned above, the utilization of biomass depends on specific purpose. Therefore, people who desire to use it as a house heating source, Ampel with $200{ }^{\circ} \mathrm{C}$ carbonization would be recommended, while as use of charcoal, Ampel with $600{ }^{\circ} \mathrm{C}$ carbonization is more suitable.

Table 5. Energy Efficiency of Original and Carbonized Bamboo Samples

\begin{tabular}{|c|c|c|c|c|c|c|}
\hline & Species & $200{ }^{\circ} \mathrm{C}$ & $400{ }^{\circ} \mathrm{C}$ & $600{ }^{\circ} \mathrm{C}$ & $800{ }^{\circ} \mathrm{C}$ & $1000{ }^{\circ} \mathrm{C}$ \\
\hline & Andong & $80.3 \pm 2.1$ & $33.9 \pm 1.3$ & $29.5 \pm 0.1$ & $26.2 \pm 1.7$ & $26.6 \pm 1.4$ \\
& Hitam & $80.9 \pm 2.2$ & $34.7 \pm 1.1$ & $29.7 \pm 3.3$ & $28.2 \pm 1.2$ & $27.6 \pm 1.0$ \\
Char yield & Tali & $82.0 \pm 0.7$ & $36.1 \pm 0.5$ & $29.5 \pm 1.2$ & $28.3 \pm 2.7$ & $27.8 \pm 1.3$ \\
(\%) & Kuning & $74.1 \pm 2.4$ & $36.3 \pm 0.4$ & $30.9 \pm 2.2$ & $29.0 \pm 0.7$ & $28.0 \pm 0.9$ \\
& Ampel & $79.6 \pm 1.5$ & $34.3 \pm 0.4$ & $29.3 \pm 2.1$ & $27.6 \pm 1.1$ & $27.0 \pm 0.7$ \\
& Betung & $82.3 \pm 3.9$ & $35.0 \pm 0.7$ & $30.8 \pm 0.7$ & $28.4 \pm 2.5$ & $27.6 \pm 2.1$ \\
\hline \multirow{4}{*}{ Energy } & Andong & $1.11 \pm 0.02$ & $1.62 \pm 0.03$ & $1.69 \pm 0.03$ & $1.64 \pm 0.02$ & $1.59 \pm 0.01$ \\
densification & Hitam & $1.10 \pm 0.03$ & $1.57 \pm 0.01$ & $1.74 \pm 0.01$ & $1.69 \pm 0.02$ & $1.68 \pm 0.01$ \\
ratio & Tali & $1.10 \pm 0.01$ & $1.66 \pm 0.01$ & $1.75 \pm 0.01$ & $1.68 \pm 0.02$ & $1.68 \pm 0.02$ \\
& Kuning & $1.11 \pm 0.03$ & $1.61 \pm 0.03$ & $1.64 \pm 0.03$ & $1.60 \pm 0.02$ & $1.61 \pm 0.03$ \\
& Ampel & $1.19 \pm 0.03$ & $1.70 \pm 0.01$ & $1.80 \pm 0.01$ & $1.75 \pm 0.03$ & $1.71 \pm 0.01$ \\
& Betung & $1.13 \pm 0.01$ & $1.54 \pm 0.00$ & $1.70 \pm 0.01$ & $1.70 \pm 0.01$ & $1.65 \pm 0.02$ \\
\hline \multirow{5}{*}{ Energy yield } & Andong & $89.2 \pm 3.8$ & $54.8 \pm 2.6$ & $49.8 \pm 0.7$ & $43.0 \pm 3.2$ & $42.2 \pm 2.0$ \\
$(\%)$ & Hitam & $89.0 \pm 0.3$ & $54.4 \pm 2.1$ & $51.8 \pm 5.8$ & $47.7 \pm 1.5$ & $46.6 \pm 2.2$ \\
& Tali & $90.1 \pm 0.6$ & $60.1 \pm 1.2$ & $51.7 \pm 1.8$ & $47.5 \pm 3.9$ & $46.8 \pm 2.3$ \\
& Kuning & $82.1 \pm 4.3$ & $58.5 \pm 0.5$ & $50.7 \pm 4.0$ & $46.5 \pm 1.6$ & $45.0 \pm 1.4$ \\
& Ampel & $96.1 \pm 1.6$ & $58.3 \pm 1.0$ & $52.9 \pm 3.6$ & $48.6 \pm 1.2$ & $46.2 \pm 1.4$ \\
& Betung & $92.8 \pm 5.3$ & $54.0 \pm 1.2$ & $52.5 \pm 0.6$ & $48.5 \pm 1.4$ & $45.7 \pm 3.2$ \\
\hline
\end{tabular}

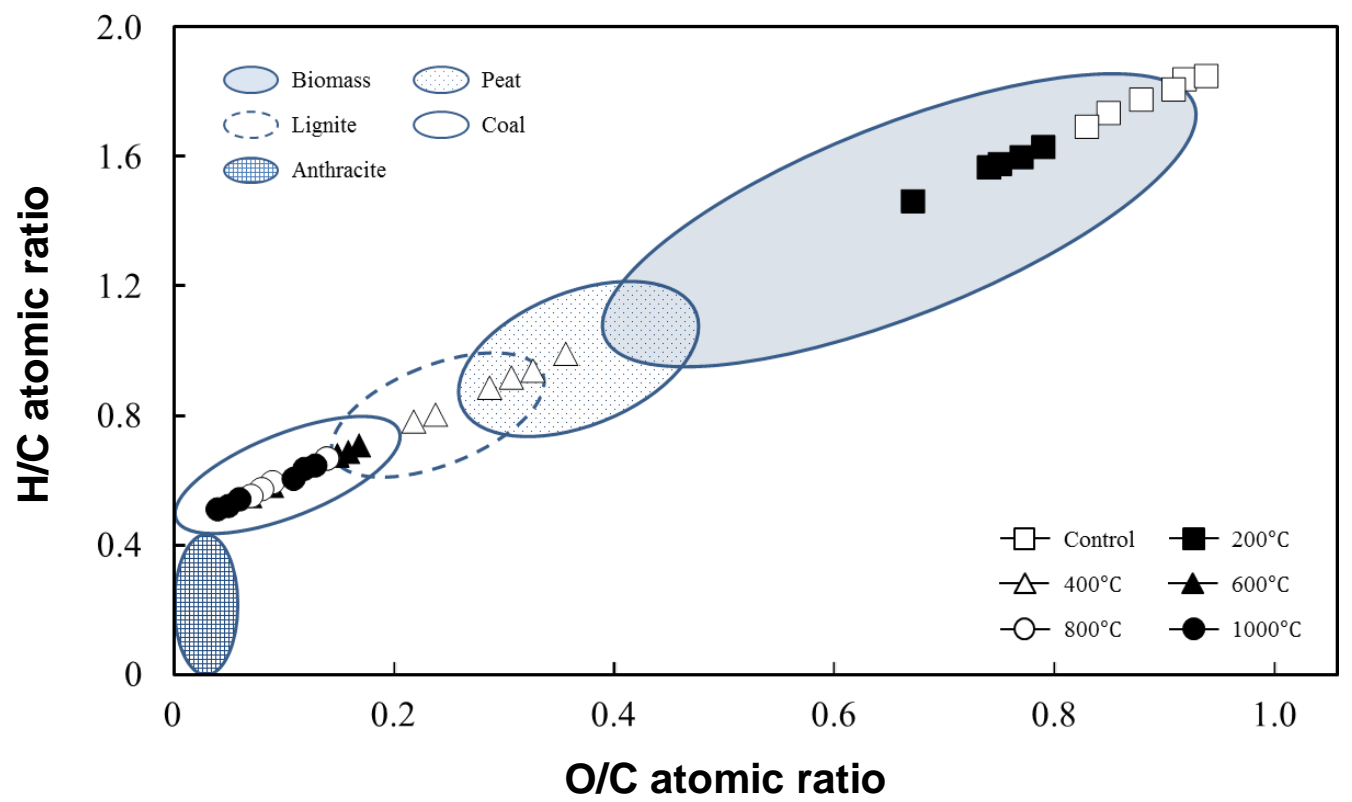

Fig. 4. Classification of the original and carbonized bamboo samples at different temperatures by hydrogen/carbon and oxygen/carbon ratios 
The van Krevelen diagram was plotted by using $[\mathrm{H} / \mathrm{C}]$ and $[\mathrm{O} / \mathrm{C}]$ ratios to evaluate the thermal maturity of carbonized bamboo as a solid fuel (Fig. 4). The original bamboo and carbonized bamboo at $200{ }^{\circ} \mathrm{C}$ belonged to a biomass grade. Carbonized bamboos at $400{ }^{\circ} \mathrm{C}$ were affiliated with a peat grade. More specifically, carbonized Ampel and Tali bamboos above $400{ }^{\circ} \mathrm{C}$ reached a thermal maturity at a lignite grade. From a carbonization temperature at $600{ }^{\circ} \mathrm{C}$, all bamboo samples showed thermal maturity at coal grade, but it was confirmed that the materials did not satisfy an anthracite grade. Jones et al. (2006) suggested that the oxygen contents should to be lower to produce higher quality liquid fuel, as oxygen reduces the calorific value and hinders the liquefaction of the fuel. In general, bamboo has a relatively high proportion of holocellulose in comparison to that of wood (Wahab et al. 2013). Therefore, to overcome limitations of biomass and replace other solid fuels, bamboo should be carbonized to at least $400{ }^{\circ} \mathrm{C}$ or higher due to the degradation of holocellulose.

\section{CONCLUSIONS}

1. The original bamboos showed $7.1 \%$ to $10.2 \%$ of moisture content (MC), $1.1 \%$ to $2.7 \%$ of the ash, $72 \%$ to $80 \%$ of volatile matter, and $10 \%$ to $18 \%$ of fixed carbon. The calorific value of all the bamboo species was $18.2 \mathrm{MJ} / \mathrm{kg}$ to $18.8 \mathrm{MJ} / \mathrm{kg}$. No significant difference of calorific value among the species was evaluated.

2. The carbonized Ampel bamboo showed the highest calorific value among the samples due to lower ash and volatile matter contents and a higher fixed carbon. In contrast, the Betung bamboo had a lower value than the other samples.

3. While carbonization at $200{ }^{\circ} \mathrm{C}$ resulted in bamboo with higher fuel efficiency, it is not preferred for use as a fuel source due to its lower calorific value. On the other hand, carbonized bamboo above $400{ }^{\circ} \mathrm{C}$ showed better thermal maturity than the conventional solid fuels even with the lower fuel efficiency.

4. Indonesian bamboo biomass carbonized at $200{ }^{\circ} \mathrm{C}$ may be suitable for household heating source as wood pellets. For usage as charcoal, bamboo should be carbonized at least $400{ }^{\circ} \mathrm{C}$ with using Ampel bamboo. Carbonization above $800{ }^{\circ} \mathrm{C}$ may not be preferred due to lower efficiency.

5. Based on these results, major Indonesian bamboos could be utilized as a fuel source in different way with varying manufacture conditions.

\section{ACKNOWLEDGEMENTS}

This study was supported by research fellowship program through the National Institute of Forest Science (NIFoS), Korea.

\section{REFERENCES CITED}

Ahn, B. J., Han, G. S., Choi, D. H., Cho, S. T., and Lee, S. M. (2014). “Assessment of the 
biomass potential recovered from oil palm plantation and crude palm oil production in Indonesia," J. Korean Wood Sci. Technol. 42(3), 231-342. DOI:

10.5658/WOOD.2014.42.3.231

Asada, T., Ishihara, S., Yamane, T., Toba, A., Yamada, A., and Oikawa, K. (2002). "Science of bamboo charcoal: Study on carbonizing temperature of bamboo charcoal and removal capability of harmful gases," J. Health Sci. 48(6), 473-479. DOI: $10.1248 /$ jhs. 48.473

Beer, L. L., Boyd, E. S., Peters, J. W., and Posewitz, M. C. (2009). "Engineering algae for biohydrogen and biofuel production," J. Curr. Opin. Biotechnol. 20(2009), 264271. DOI: 10.1016/j.copbio.2009.06.002

Biagini, E., Fantei, A., and Tognotti, L. (2008). "Effect of the heating rate on the devolatilization of biomass residues," Thermochim Acta. 472(2009), 55-63. DOI: 10.1016/j.tca.2008.03.015

Bial, M., Asgher, M., and Basu, P. (2013). Biomass Gasfication, Pyrolysis and Torrefaction, $2^{\text {nd }}$ Ed., Academic Press, San Diego, CA, United States.

Bilal, M., Asgher, M., Iqbal, H. M. N., and Ramzan, M. (2017). "Enhanced bio-ethanol production from old newspapers waste through alkali and enzymatic delignification," Waste Biomass Valori. 8, 2271-2281. DOI: 10.1007/s12649-017-9871-7

Demirabaş, A. (2003). "Biodiesel fuels from vegetable oils via catalytic and non-catalytic supercritical alcohol transesterifications and other method: A survey," Energy Conver. Manag. 44(2003), 2093-2109. DOI: 10.1016/S0196-8904(02)00234-0

Hardiani, N., and Dewy, K. K. (2014). Indonesia Invites. $2^{\text {nd }}$ Ed., Ministry of Foreign Affairs of the Republic of Indonesia, Jakarta, Indonesia.

Hernandez-Mena, L. E., Pécoraa, A. A., and Beraldob, A. L. (2014). "Slow pyrolysis of bamboo biomass: Analysis of biochar properties," Chem. Eng. Transaction 37(2014), 115-120. DOI: 10.3303/CET1437020

Hidayat, W., Qi, Y., Jang, J. H., and Febrianto, F. (2017). “Carbonization characteristics of juvenile woods from some tropical trees planted in Indonesia," J. Dep. Agric. Kyushu Univ. 62(1), 145-152.

Jones, J. M., Nawaz, M., Dravell, L. I., Ross, A. B., Pourkashanian, M., and Williams, A. (2006). Towards Biomass Classification for Energy Application: Science in Thermal Chemical Biomass Conversion, $1^{\text {st }}$ Ed., CPL Press, Berkshire, UK.

Khandaker, S., Kuba, T., Kamida, S., and Uchikawa, Y. (2017). "Adsorption of cesium from aqueous solution by raw and concentrated nitric acid-modified bamboo charcoal," J. Environ. Chem. Eng. 5(2), 1456-1464. DOI: 10.1016/j.jece.2017.02.014

Klass, D. L. (1998). Biomass for Renewable Energy, Fuels, and Chemicals, Academic Press, San Diego.

KSA, KS E ISO 562 (2012). "Hard coal and coke - Determination of volatile matter," Korean Standards Association, Seoul, Korea.

KSA, KS E ISO 1171 (2012). "Solid mineral fuels - Determination of ash contents," Korean Standards Association, Seoul, Korea.

KSA, KS E 3707 (2016). "Determination of calorific value of coal and coke," Korean Standards Association, Seoul, Korea.

Kumar, R., and Chandrashekar, N. (2014). "Characteristics of charcoal from some promising bamboo species," J. Indian Acad. Wood Sci. 11(2), 144-149. DOI: 10.1007/s13196-014-0128-9

Park, S. B., Kwon, S. D., Ahn, K. D., and Cha, S. H. (1998). "Characteristics of bamboo charcoal (I)," in: Proceeding from the $65^{\text {th }}$ Annual Meeting of the Korean Society of 
Wood Science and Technology, Seoul, Korea, pp. 266.

Park, S. B., and Park, J. S. (2012). "Combustion characteristics of bamboo charcoal boards," J. Korean Wood Sci. Technol. 40(1), 19-25. DOI: 10.5658/WOOD.2012.40.1.19

Park, S. W., Jang, J. H., Wistara, N. J., Hidayat, W., Lee, M., Febrianto, F. (2018). "Anatomical and physical properties of Indonesian bamboo carbonized at different temperatures," J. Korean Wood Sci. Technol. 46(6), 656-669. DOI: 10.5658/WOOD.2018.46.6.656

Pimchuai, A., Dutta, A., and Basu, P. (2010). "Torrefaction of agriculture residue to enhance combustible properties," Energy Fuel 24(9), 4638-4645. DOI: 10.1021/ef901168f

Qian, J. M., Wang, J. P., Qiao, G. J., and Jin, Z. H. (2004). 'Preparation of porous SiC ceramic with a wood-like microstructure by sol-gel and carbothermal reduction processing," J. European Ceram. Soc. 24(2004), 3251-3259. DOI: 10.1016/j.jeurceramsoc.2003.10.042

Sims, R. E. H. (2004). "Renewable energy: A response to climate change," J. Solar Energy 76(9), 9-17. DOI: 10.1016/S0038-092X(03)00101-4

Sun, Z. Y., Tang, Y. Q., Iwanaga, T., Sho, T., and Kida, K. (2011). "Production of fuel ethanol from bamboo by concentrated sulfuric acid hydrolysis followed by continuous ethanol fermentation," Bioresource Technol. 102(2011), 10929-10935. DOI: 10.1016/j.biortech.2011.09.071

Wahab, R., Mustafa, M. T., Salam, M. A., Suding, M., Samsi, H. W., and Rasat, S. M. (2013). "Chemical composition of four cultivated tropical bamboo in genus Gigantochola," J. Agric. Sci. 5(8), 66-75. DOI: 10.5539/jas.v5n8p66

Yudodibroto, H. (1985). "Bamboo research in Indonesia," in: Proceeding from the International Bamboo Workshop, Hangzhou, China, pp. 33.

Zuo, S. L., Gao, S. Y., Yuan, X. G., and Xu, B. S. (2003). "Carbonization mechanism of bamboo (Phyllostachys) by means of Fourier Transform Infrared and elemental analysis," J. Forestry Res. 14(1), 75-79. DOI: 10.1007/BF02856768

Article submitted: February 7, 2019; Peer review completed: March 23, 2019; Revised version received and accepted: April 6, 2019; Published: April 12, 2019.

DOI: 10.15376/biores.14.2.4224-4235 